\title{
Predictive features for histology of gastric subepithelial lesions
}

\author{
Ricardo Teles SCHULZ1', Lizandra Castilho FABIO², Matheus Cavalcante FRANCO', \\ Sheila A SIQUEIRA ${ }^{3}$, Paulo SAKAI ${ }^{1}$ and Fauze MALUF-FILHO' ${ }^{1}$
}

Received 5/7/2016

Accepted 13/9/2016

\begin{abstract}
Background - Gastric subepithelial lesion is a relatively common diagnosis after routine upper endoscopy. The diagnostic workup of an undetermined gastric subepithelial lesion should take into consideration clinical and endoscopic features. Objective - We aimed to investigate the association between patients' characteristics, endoscopic and echographic features with the histologic diagnosis of the gastric subepithelial lesions. Methods - This is a retrospective study with 55 patients, who were consecutively diagnosed with gastric subepithelial lesions, from October 2008 to August 2011. Patients' characteristics, endoscopic and echografic features of each gastric subepithelial lesion were analysed. Histologic diagnosis provided by EUS-guided fine needle aspiration or endoscopic/surgical resection was used as gold standard. Results - The probability of gastrointestinal stromal tumors to be located in the cardia was low $(4.5 \%)$, while for leiomyoma it was high ( $>95 \%)$. In addition, there was a higher risk of gastrointestinal stromal tumors in patients older than 57 years (OR 8.9; 95\% CI), with lesions $\geq 21 \mathrm{~mm}$ (OR 7.15; 95\% CI), located at 4th layer (OR 18.8; 95\% CI), with positive Doppler sign (OR 9; 95\% CI), and irregular outer border (OR 7.75; 95\% CI). Conclusion - The location of gastric subepithelial lesions in the gastric cardia lowers the risk of gastrointestinal stromal tumors. While gastric subepithelial lesions occurring in elderly patients, located in the gastric body, with positive Doppler signal and irregular outer border increase the risk of gastrointestinal stromal tumors.
\end{abstract}

HEADINGS - Endosonography. Fine-needle biopsy. Endoscopy. Gastrointestinal stromal tumors. Stomach neoplasms.

\section{INTRODUCTION}

Gastric subepithelial lesions (GSLs) are identified in about $0.4 \%$ of patients undergoing an upper GI endoscopy ${ }^{(4)}$. The nature of GSLs ranges from a wide variety of benign lesions to tumors with a high malignant potential ${ }^{(12-14)}$. However, endoscopic appearance and conventional biopsies have limited diagnostic accuracy for diagnosis of subepithelial lesions in the GI $\operatorname{tract}^{(9,10)}$.

Endoscopic ultrasound (EUS) is the most appropriate tool for characterization of the GSLs. Its features can distinguish intramural from extrinsic lesions, assess the layers of the GI wall, characterize the sonographic appearance, and also provide tissue analyses through the endoscopic ultrasound-guided fine needle aspiration (EUS-FNA) $)^{(8,11)}$.

The aim of this study was to assess whether the combination of clinical, endoscopic and echographic features may be predictors for the definitive histological diagnosis of gastric subepithelial lesions.

\section{METHODS}

\section{Study design}

This was a retrospective study with adult patients ( $\geq 18$ years old) consecutively diagnosed with GSLs and submitted to EUS, between October 2008 and August 2011.

The following clinical and EUS features were recorded for each case: (a) age (years); (b) gender; (c) maximal diameter (mm); (d) echogenicity; (e) heterogeneity (homogeneous vs heterogeneous); (f) layer of origin in the gastric wall; (g) regularity of the outer border (regular vs irregular); (h) intra-tumoral flow detected by power Doppler (absent or present); (i) topographic distribution of the GSL in the stomach (cardia, body, antrum, and fundus).

For definitive diagnosis, patients could also be submitted to EUS-FNA, endoscopic and/or surgical resection. Definitive diagnosis refers strictly to GSLs with conclusive histopathological and immunohistochemical analysis.

The EUS and EUS-FNA were performed under conscious sedation in a single center with linear array echoendoscopes (Olympus GFUCT-160) and 22-gauge needles (Cook Medical, Winston-Salem, NC). The specimens were placed in formalin for histopathological analysis. After examination of the H\&E-stained cell-block material, immunohistochemical analysis was ordered at the discretion of the pathologist. On-site cytologic evaluation was not available. Patients who were submitted to endoscopic or surgical resection also had samples referred to histopathological analysis.

\section{Statistics}

Quantitative variables were expressed as means \pm SD or medians (ranges). Qualitative variables were expressed as frequencies and percentages. Logistic analysis was performed with chi-square test, Fisher's exact test, Mann-Whitney test and kappa test. $P$ value $<0.05$ was considered statistically significant. Statistical analysis was performed using SPSS for Windows (version 19.0; SPSS Inc, Chicago).

Declared conflict of interest of all authors: none

Disclosure of funding: no funding received

${ }^{1}$ Departamento de Gastroenterologia, Faculdade de Medicina, Universidade de São Paulo, SP. Brasil' 2 Departamento de Estatística, Instituto de Matemática, Universidade Federal da Bahia (UFBA), Salvador, BA, Brasil; ${ }^{3}$ Departamento de Patologia, Faculdade de Medicina, Universidade de São Paulo, SP, Brasil.

Correspondence: Ricardo Teles Schulz. Departamento de Gastroenterologia, Faculdade de Medicina, Universidade de São Paulo. Av. Dr. Enéas de Carvalho Aguiar, 255. Bairro Cerqueira César - CEP: 05403-000 - São Paulo, SP, Brasil. E-mail: ricardo-schulz@hotmail.com 


\section{Ethics}

This study was reviewed and approved by the Ethics Committee of our institution and was conducted in accordance with the World Medical Association Declaration of Helsinki-Ethical Principles for Medical Research Involving Human Subjects.

\section{RESULTS}

A total of 87 patients with GSLs submitted to endoscopy and EUS were enrolled in this study. However, 32 cases were excluded due to insufficient material for definitive histopathological diagnosis.
Tables 1 and 2 show patients clinical characteristics, endoscopic and echographic features of GSLs according to the histopathologic diagnosis. The relative distribution of the lesions in the remaining 55 patients was the following: $21(38.1 \%)$ were GISTs (Figure 1 and 2); $13(23.6 \%)$ leiomyoma (Figure 3$) ; 12(21.8 \%)$ ectopic pancreas; $5(9.0 \%)$ lipomas; $2(3.6 \%)$ schwannomas (Figure 4); and $2(3.6 \%)$ mesenquimal lesions with negative immunohistochemical analysis. Three cases were included with sufficient material obtained after surgical resection: two were GISTs; and one schwannoma. One case of ectopic pancreas was endoscopically resected, and one case of GIST was diagnosed by endoscopic biopsy. The remaining 50 cases were diagnosed by EUS-FNA.

TABLE 1. Clinical background and endoscopic/echographic features of gastric subepithelial lesions

\begin{tabular}{|c|c|c|c|c|c|c|c|}
\hline Diagnosis & $\begin{array}{c}\text { Gender } \\
(\mathbf{M} / \mathrm{F})\end{array}$ & $\begin{array}{c}\text { Median age } \\
\text { (years) }\end{array}$ & $\begin{array}{l}\text { Median size } \\
\quad(\mathrm{mm})\end{array}$ & Cardia (\%) & Fundus (\%) & Body $(\%)$ & Antrum (\%) \\
\hline Leiomyoma $(\mathrm{n}=13)$ & $10 / 3 *$ & $48.4(23-64)$ & $31.3(8-100)$ & $11(84) * * *$ & 0 & $1(7)$ & $1(7)$ \\
\hline Ectopic pancreas $(\mathrm{n}=12)$ & $3 / 9$ & $42.4(25-65)$ & $12(7-17)$ & 0 & 0 & $1(8)$ & $11(91)$ \\
\hline Other $(n=4)$ & $2 / 2$ & $55.7(31-65)$ & $27.5(15-49)$ & 0 & 0 & $2(50)$ & $2(50)$ \\
\hline
\end{tabular}

M: male; F: female; y: years; mm: millimeter. $* P=0.023 ; * * P=0.004, * * * P<0.000$. $\dagger$ One case of lipoma without topography data.

TABLE 2. Correlation between echographic features and type of gastric subepithelial lesions

\begin{tabular}{|c|c|c|c|c|c|}
\hline \multirow{2}{*}{$\begin{array}{l}\text { Echoendoscopic } \\
\text { features }\end{array}$} & \multicolumn{5}{|c|}{ Diagnosis } \\
\hline & GIST & Leiomyoma & $\begin{array}{c}\text { Ectopic } \\
\text { pancreas }\end{array}$ & Lipoma & Other \\
\hline $\begin{array}{l}\text { Positive Doppler } \\
\text { signal }\end{array}$ & $5 *$ & 1 & 0 & 0 & 0 \\
\hline $\begin{array}{l}\text { Irregular outer } \\
\text { border }\end{array}$ & $7 * *$ & 2 & 0 & 0 & 0 \\
\hline $\begin{array}{l}\text { Heterogeneous } \\
\text { aspect }\end{array}$ & 9 & 6 & $10 * * *$ & 2 & 3 \\
\hline Hyperechoic lesion & 1 & 2 & 0 & 4 & 0 \\
\hline Hyperechoic foci & 2 & 3 & 0 & 1 & 1 \\
\hline Cystic spaces & 3 & 1 & 0 & 0 & 0 \\
\hline
\end{tabular}

Layer of origin

$\begin{array}{lccccc}\text { 4th } & 19 \dagger & 11 \text { † } & 1 & 0 & 4 \\ \text { 4th \& 3rd } & 1 & 1 & 0 & 0 & 0 \\ 3 \text { rd } & 1 & 0 & 3 & 5 & 0 \\ \text { 3rd \& 2nd } & 0 & 1 & 7 & 0 & 0 \\ \text { 2nd } & 0 & 0 & 1 & 0 & 0\end{array}$

${ }^{*} P$-value $=0.070 ;{ }^{* *} P$-value $=0.016,{ }^{*} * P$-value $=0.024, \dagger P$-value $=0.001, \$ P$-value $=0.035$. *Although not significant at $P=5 \%$, the variable Doppler positive was considered for further analysis because of the diagnostic association trend.

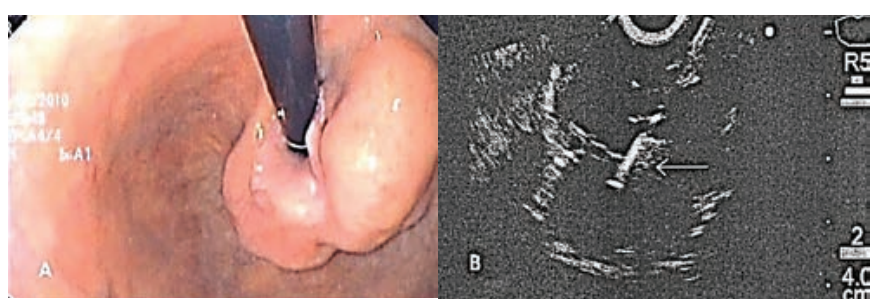

FIGURE 1. A. Endoscopic view of a subepithelial lesion in the cardia. B. Endosonographic image of the same lesion during procedure with intra-lesional neddle (arrow) aspiration (EUS-FNA)

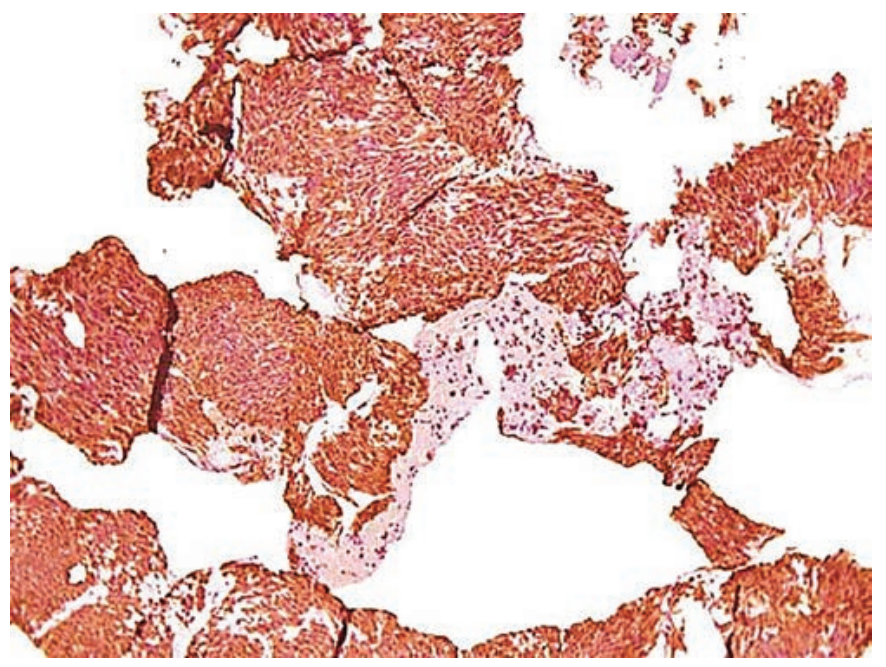

FIGURE 2. Sample obtained by EUS-FNA showed GIST (cell block), with positive stain for CD34 (100x magnification) 


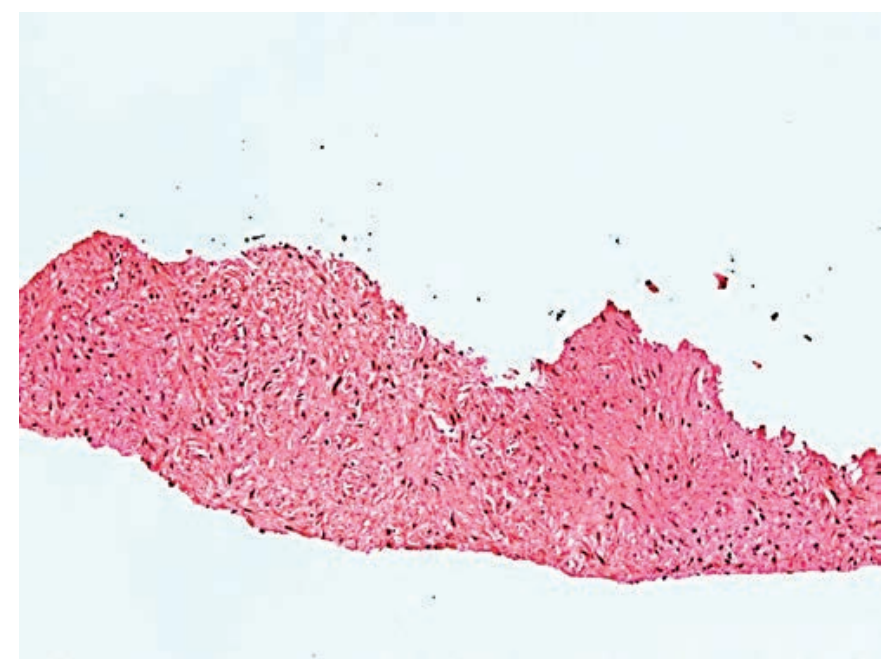

FIGURE 3. Sample obtained by EUS-FNA showed leiomyoma (cell block). (H\&E, 100x magnification)

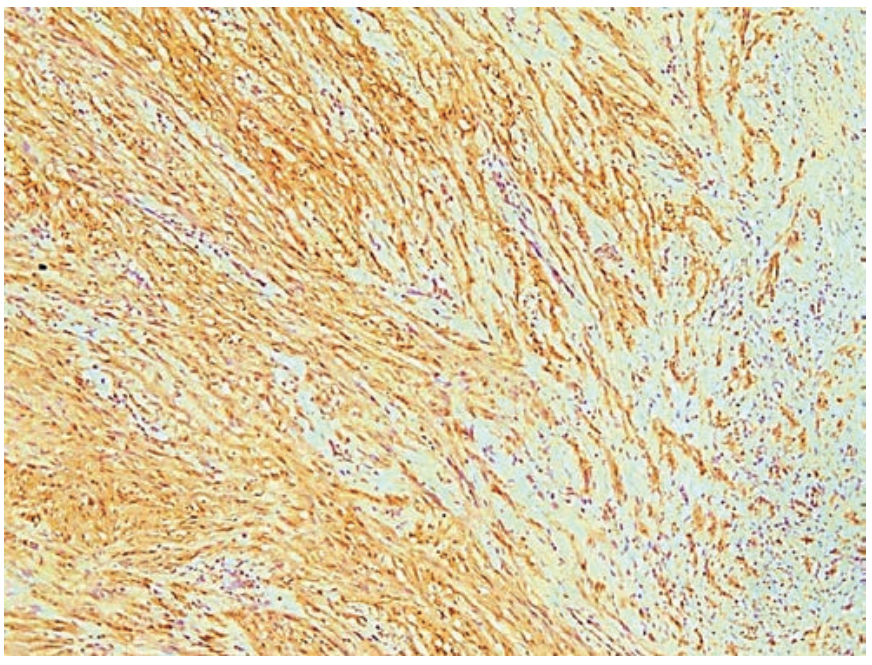

FIGURE 4. Sample obtained by EUS-FNA showed schwannoma (cell block), with positive stain for S100 (100x magnification)

The EUS localization in the 4th layer of gastric wall (muscularis propria) was 18 times more probable for GIST [95\% confidence interval (CI), 16.7-20.9], and seven times for leiomyoma $(95 \% \mathrm{CI}$, 5.2-9.5). The presence of positive Doppler signal (OR 9; $95 \% \mathrm{CI}$, 6.6-11.4) and irregular outer border (OR 7.7; 95\% CI, 6-9.4) were associated with GIST. Echographic heterogeneity was associated with ectopic pancreas (OR 5.75; 95\% CI, 4.1-7.3). Kappa test was done to confirm association between the above cited EUS features and histopathologic diagnosis.

The GSLs were topographically distributed in the 55 patients as follows: $23(41.8 \%)$ in the antrum, $17(30.9 \%)$ body, $11(20 \%)$ cardia, and four $(7.2 \%)$ fundus. We observed a negative association between GIST and lesions located in the cardia $(P=0.004$, chisquare test). Logistic regression tests confirmed that statement, once for lesions located in the cardia the probability of GIST was only $4.5 \%$. We also found that it is almost 20 times more probable a GIST to be located in a different gastric segment than in the cardia (OR 19.21; 95\% CI, 16.1-22.2). On the other hand, there was a positive association between leiomyoma and lesions located in the cardia $(P<0.001$, chi-square test). (Figure 2$)$ In fact, the chance of a GSL located in the cardia to be leiomyoma is high. In this study it was $95.8 \%$, with odds of almost 400 when compared with others diagnosis (OR 390; 95\% CI, 387-394). As presumed, the diagnosis of ectopic pancreas also presented a negative association with lesions located in the cardia $(P=0.04$, chi-square test $)$, but in our sample this finding was not confirmed with logistic analysis (OR $0.11 ; 95 \%$ CI, $-2.9-3.1$ ).

According to the diameter, we observed that lesions $<15.5 \mathrm{~mm}$ had a higher probability of ectopic pancreas diagnosis $(P<0.001$, Mann Whitney test), and lesions $<21 \mathrm{~mm}$ had a lower probability of GIST diagnosis ( $P=0.001$, Mann Whitney test). And for GSLs $\geq 21 \mathrm{~mm}$ the chance of being diagnosed as GIST was seven times higher (OR 7; 95\% CI, 5.88-8.43).

Leiomyoma was less common in women $(P=0.023$, chi-square test). Age was a predictive factor only for ectopic pancreas and GISTs ( $P=0.009$ and $P=0.00001$, respectively; Mann Whitney test). GISTs were more common in patients older than 57.5 years (OR 8.9; 95\% CI, 7.66-10.2).

Finally, multiple regression analysis indicates location in the cardia, lesion outside the 4th layer, and diameter of up to $20 \mathrm{~mm}$ as significant variables to exclude GIST diagnosis, and this regression analysis showed an area under the ROC (receiver operating characteristic) curve of 0.955 (95\% CI, 0.88-1.00), with sensitivity, specificity, negative and positive predictive values of $100 \%, 90.9 \%$, $100 \%$ and $97 \%$, respectively.

\section{DISCUSSION}

GISTs are considered potentially malignant lesions. Its appearance and samples obtained by biopsy forceps usually have limited diagnostic accuracy, which explains the recommendation to pursue a conclusive diagnosis of an undetermined GSL with EUS and FNA. The echographic aspects of a hypoechoic lesion in the 4th layer preclude some diagnosis, but do not differentiate a GIST from leiomyoma or schwannoma. The EUS-FNA has a diagnostic accuracy of $60 \%-70 \%$ that decreases for lesions smaller than $20 \mathrm{~mm}$. In this context, it is valid the search for clinical, endoscopic or echographic factors that may be helpful for predicting the GIST diagnosis, and could compose a strategy for risk stratification of undetermined GSLs.

In this study we observed that diagnosis of GIST and ectopic pancreas was associated with older age. These findings could be explained by the persistence in pursuing the correct diagnosis of a subepithelial lesion in older patients due to the fear of malignancy. Ectopic pancreas was also more likely in lesions smaller than 12 $\mathrm{mm}$. An explanation for that may lie in the fact that it is easier and more comfortable for the pathologist to detect pancreatic tissue in limited EUS-FNA samples.

Ours results show that the location in the cardia of a GSL is strongly predictive of leiomyoma. Therefore, it could mean that before indicating resection of a GSL located at the cardia, the tissue diagnosis should be pursued as the risk of GIST is very low in this location. On the other hand, we observed the location of a GSL in the gastric body favored the diagnosis of GIST. Our findings were corroborated by a large study with 143 cases of GSLs located at the cardia that were resected by ESD. Most lesions proved to be leiomyoma, while only $14 \%$ were GISTs ${ }^{(6)}$. Another study described the follow-up of 50 patients with GSLs. The authors found that 
distal location was a risk factor for tumor growth (OR 5.08; $95 \%$ CI, 1.37-18.8), which could corroborate with our finding of location in the cardia as a protective factor against GISTs ${ }^{(3)}$.

In our study, only the presence of irregular outer border was associated with GIST $(P<0.05$, chi-square test), while the presence of positive Doppler signal showed a trend for association $(P=0.07$, chi-square tests). Although the findings above could be predictive factors for histological diagnosis, they were found only in 8 of 21 $(38 \%)$ cases of gastric GISTs, compromising the negative predictive value of these findings. In other words, the absence of these findings cannot exclude the diagnosis of GIST. In fact, the presence of these findings increases the risk of a GSL being GIST and, in a context of a negative biopsy, it may have a significant impact on the clinical management. A retrospective study comparing $17 \mathrm{c}$-kit positive mesenchymal tumors (including 13 gastric tumors) and 12 c-kit negative ones (with eight esophageal tumors) found a trend for GIST diagnosis for lesions $>40 \mathrm{~mm}$, with ulceration and/or internal cystic spaces, but the study did not assess the regularity of the outer border or presence of Doppler signal ${ }^{(5)}$. A retrospective study of 141 patients with GSLs concluded that the presence of cystic spaces and irregular outer border were predictive of GISTs ${ }^{(7)}$. The authors did not report the use of Doppler. Another study included 37 patients with definitive diagnosis of GIST, and in only six cases irregular outer border was present. Once again the presence of Doppler sign was not evaluated ${ }^{(12)}$.

Several limitations of our study need to be addressed. The results were limited by the availability and quality of documentation due to the retrospective design. Additionally, histology of surgical specimens was not available in all patients because the benign lesions diagnosed by EUS-FNA were not resected, and some patients with GISTs smaller than $20 \mathrm{~mm}$ preferred a non-surgical follow-up, in accordance with the current consensus.

Another limitation was the inability to establish diagnosis with EUS-FNA in 32 (37\%) cases. As previously mentioned, diagnostic yield of EUS-FNA ranges from $60 \%$ to $70 \%$, and smaller is the lesion, lower is that result. To increase the diagnostic accuracy of EUS-FNA, core biopsy needles were developed. However, a prospective study with EUS guided trucut biopsy did not report any significant result from EUS-FNA for diagnosis of subepithelial lesions ${ }^{(2)}$. And also a recent meta-analysis comparing EUS-FNA with EUS guided fine needle biopsy (EUS-FNB) for different lesions, including GSLs, showed similar diagnostic yield (about 65\% for each one technique ${ }^{(1)}$. Therefore, the use of new models of core biopsy needles does not seem to increase the diagnostic yield for GSLs. In accordance with previous reports, it was observed in our study that the EUS-FNA diagnostic yield reached $63 \%$.

It is possible that the final diagnosis of the remaining 32 cases could have changed our findings. However, this is a limitation dictated by the clinical scenario, and our findings are supported by the literature.

EUS was performed by at least four operators. This fact probably introduced an interobserver variation in the performance of EUS, which was not studied. Actually, the objective of the study was not to determine the diagnostic yield of EUS-FNA or interobserver variation in the performance of EUS, but the correlation of clinical, endoscopic and echographic features of GSLs and the diagnosis obtained by EUS-FNA or resection.

The current study reflects the limitations of the routine EUS use in the management of incidental GSLs. Further prospective studies are suggested, taking into consideration the potential of new information aggregated by this study. Despite the above mentioned limitations, our results offer a possibility for new insights regarding specific and non-invasive parameters readily available, such as topography of the GSLs.

In conclusion, the location of a GSL in the gastric cardia lowers the risk of GIST. While a GSL occurring in an elder patient, located in the gastric body, with positive Doppler signal and irregular outer border increases the risk of GIST.

\section{Authors' contributions}

Shulz RT: conception and design; analysis and interpretation of the data; drafting of the article. Fabio LC: analysis and interpretation of the data. Franco MC: critical revision of the article for important intellectual content. Siqueira SA: analysis and interpretation of the data. Sakai P: critical revision of the article for important intellectual content. Maluf-Filho F: conception and design; critical revision of the article for important intellectual content; final approval of the article.

Schulz RT, Fabio LC, Franco MC, Siqueira SA, Sakai P, Maluf-Filho F. Fatores preditivos da histologia nas lesões subepiteliais gástricas. Arq Gastroenterol. 2017,54(1):11-5.

RESUMO - Contexto - O diagnóstico das lesões subepiteliais gástricas é relativamente comum após a endoscopia digestiva alta de rotina. A posterior investigação diagnóstica de uma lesão subepitelial gástrica indeterminada deve levar em consideração os aspectos clínicos e endoscópicos. Objetivo O objetivo foi avaliar a associação entre as características particulares dos pacientes, endoscópicas e ecográficas dos casos de lesões subepiteliais gástricas com os seus diagnósticos histológicos finais. Métodos - Estudo retrospectivo com 55 pacientes, consecutivamente diagnosticados com lesão subepitelial gástrica de outubro de 2008 a agosto de 2011. As características do paciente, endoscópica e ecográfica de cada caso com lesão subepitelial gástrica foram analisadas. O diagnóstico histológico fornecido pela punção aspirativa com agulha fina guiada por ecoendoscopia e/ou a ressecção endoscópica/cirúrgica foram utilizadas como padrão-ouro. Resultados - A probabilidade de tumor estromal gastrintestinal ser localizado na cárdia foi baixa $(4,5 \%)$, enquanto que para o leiomioma foi elevada ( $>95 \%)$. Além disso, houve um maior risco de tumor estromal gastrintestinal em pacientes acima de 57 anos (OR 8,9; IC 95\%), com lesão $\geq 21 \mathrm{~mm}$ (OR 7,15; IC 95\%), localizada na 4 a camada (OR 18,8; IC 95\%), com sinal positivo no Doppler (OR 9; IC 95\%), e borda externa irregular (OR 7,75; IC 95\%). Conclusão - A localização de uma lesão subepitelial gástrica na cárdia reduz o risco de tumor estromal gastrintestinal. Enquanto que lesões subepiteliais gástricas que ocorrem em pacientes idosos, localizadas no corpo gástrico, com sinal positivo no Doppler e com borda externa irregular aumentam significativamente o risco de tumor estromal gastrintestinal.

DESCRITORES - Endossonografia. Biópsia por agulha fina. Endoscopia. Tumores do estroma gastrointestinal. Neoplasias gástricas. 


\section{REFERENCES}

1. Bang JY, Hasan M, Hawes RH, Varadarajulu S. EUS-Guided Tissue Acquisition Meta-Analysis Comparing the Procore and Standard FNA Needles. Gastrointest Endosc. 2014;79:AB427.

2. Fernández-Esparrach G, Sendino O, Solé M, Pellisé M, Colomo L, Pardo A, et al. Endoscopic ultrasound-guided fine-needle aspiration and trucut biopsy in the diagnosis of gastric stromal tumors: a randomized crossover study. Endoscopy. 2010;42:292-9.

3. Hata S, Arai M, Suzukib T, Maruoka D, Matsumura T, Nakagawa T, et al. Clinical significance of endoscopic ultrasound for gastric submucosal tumors. Clin Res Hepatol Gastroenterol. 2013;37:207-12.

4. Hedenbro JL, Ekelund M, Wetterberg P. Endoscopic diagnosis of submucosal gastric lesions. The results after routine endoscopy. Surg Endosc. 1991;5:20-3.

5. Hunt GC, Rader, AE, Faigel DO. A comparison of EUS features between CD117 positive GI stromal tumors and CD-117 negative GI spindle cell tumors. Gastrointest Endosc. 2003;57:469-74.

6. Li QL, Yao LQ, Zhou PH, Xu MD, Chen SY, Zhong YS, et al. Submucosal tumors of the esophagogastric junction originating from the muscularis propria layer: a large study of endoscopic submucosal dissection (with video). Gastrointest Endosc. 2012;75:1153-8.

7. Mekky MA, Yamao K, Sawaki A, Mizuno N, Hara K, Nafeh MA, et al. Diagnostic utility of EUS-guided FNA in patients with gastric submucosal tumors. Gastrointest Endosc. 2010;71:913-9.
8. Parmar K, Waxman I. Endosonography of Submucosal Lesions. Techniques in Gastrointestinal Endoscopy. 2000;2:89-93.

9. Rösch T, Kapfer B, Will U, Baronius W, Strobel M, Lorenz R, et al. Accuracy of endoscopic ultrasonography in upper gastrointestinal submucosal lesions: a prospective multicenter study. Scand J Gastroenterol. 2002;37:856-62.

10. Rösch T, Lorenz R, Dancygier H, von Wickert A, Classen M. Endosonographic diagnosis of submucosal upper gastrointestinal tract tumors. Scand J Gastroenterol. 1992;27:1-8.

11. Sandhu IS, Bhutani MS. Gastrointestinal endoscopic utrasonography. Med Clin N Am. 2002;86:1289-317.

12. Sepe PS, Moparty B, Pitman MB, Saltzman JR, Brugge WR. EUS-guided FNA for the diagnosis of GI stromal cell tumors: sensitivity and cytologic yield. Gastrointest Endosc. 2009;70:254-61.

13. von Mehren M, Benjamin RS, Bui MM, Casper ES, Conrad EU 3rd, DeLaney TF, et al. Soft tissue sarcoma, version 2.2012; featured updates to the NCCN guidelines. J Natl Compr Canc Netw. 2012;10:951-60.

14. Yasuda K, Cho E, Nakajima M, Kawai K. Diagnosis of submucosal lesions of the upper gastrointestinal tract by endoscopic ultrasonography. Gastrointest Endosc. 1990;36:S17-S20. 